\title{
Vitamin composition of ethnic foods commonly consumed in Europe
}

\author{
Santosh Khokhar'*, Olusegun James Oyelade', Luisa Marletta², \\ Danit Shahar ${ }^{3}$, Jane Ireland ${ }^{4}$ and Stefaan de Henauw ${ }^{5}$
}

'School of Food Science and Nutrition, University of Leeds, UK; ${ }^{2}$ National Institute for Research on Food and Nutrition, Rome, Italy; ${ }^{3}$ The S. Daniel Abraham International Centre for Health and Nutrition, Ben-Gurion University, Beer-Sheva, Israel; ${ }^{4}$ French Food Safety Agency, Maisons-Alfort, France; ${ }^{5}$ Department of Public Health, Ghent University, Ghent, Belgium

\section{Abstract}

Background: Vitamin analyses are particularly important for estimating dietary intakes, determining nutritional status and regulating food labelling. Due to the increased popularity of ethnic foods, the vitamin composition of these foods is required to ensure that national food databases are up-to-date.

Objectives: The key objective of this study was to generate new and reliable data on the contents of fat-soluble vitamins, including vitamins $\mathrm{A}$ (all trans-retinol), $\mathrm{D}_{3} \& \mathrm{E}$ ( $\alpha$-tocopherol) and those that are water-soluble (vitamins $\mathrm{B}_{6}, \mathrm{~B}_{12}, \mathrm{C}$, biotin, folate, niacin, pantothenic acid, riboflavin, and thiamin) in ethnic foods commonly consumed in Europe.

Design: Thirty commonly-consumed ethnic foods in Europe (from Belgium, France, Israel, Italy, The Netherlands, and the UK) were analysed using harmonised methodologies for identification of representative foods, sampling, data scrutiny and documentation to generate reliable data. Analyses were carried out using International standard methods.

Results: Certain vitamins were present in appreciable amounts: $\beta$-carotene in tayer leaves $(7919 \mu \mathrm{g} / 100 \mathrm{~g})$, thiamin in frik dry $(0.24 \mathrm{mg} / 100 \mathrm{~g})$, riboflavin in mbinzo worms $(0.79 \mathrm{mg} / 100 \mathrm{~g}$,) and niacin in commercial soy patty $(17.5 \mathrm{mg} / 100 \mathrm{~g})$. However, retinol, pantothenic acid, vitamins $\mathrm{D}$ and $\mathrm{B}_{12}$ were below detectable levels in the majority of the foods analysed.

Conclusions: The majority of the foods contained most of the water-soluble vitamins but lacked fat-soluble vitamins. However, these preliminary data represent only a small number of foods per country and so no conclusions about vitamin imbalances can be drawn. Additional data are required on a much wider range of commonly-consumed ethnic foods to make firm conclusions about adequacy of diets.

Keywords: ethnic foods; vitamins; food composition; immigrant foods

$\mathrm{V}$ itamins have important nutritional, metabolic and physiological roles, and optimal intakes, through diet, are required to reduce the risk of deficiencies and associated diseases. Intake of excessive amounts of vitamins $\mathrm{C}, \mathrm{D}$ and $\beta$-carotene from dietary or supplement sources may be associated with reduced risk of chronic diseases such as heart disease (1-3) and certain cancers $(4,5)$. Although the risk of vitamin deficiencies amongst well-fed populations is low, lifethreatening risks in low-income countries are found. Thus dietary deficiency of vitamin A presents a major threat to life from night blindness and keratomalacia in both children and adults from the sub-continents of India and Africa (6), and poor immunity in Chinese children (7).
Recently, widespread vitamin D deficiency in newborns and pregnant mothers in Urban Massachusetts has been reported (8), and has also been found to be associated with an increased risk of rickets in toddlers, children and adolescents (9-12). The incidence of vitamin D deficiency is widely reported to be increasing and might be due to both inadequate dietary intakes and limited exposure to the sun due to changes in lifestyles of adults and children. The study in Urban Massachusetts also reported that skin colour was found to be a risk for vitamin D deficiency in mothers, whereas race/ ethnicity was a statistically-higher risk for this deficiency in infants leading to the suggestion that the association with variable race/ethnicity may include unidentified and unmeasured confounders that have an important 
bearing on infant vitamin $\mathrm{D}$ status but not on maternal vitamin D status (8). Water-soluble vitamins such as folate are important for reducing the risk of both neural tube defects (NTDs) (13) heart disease by lowering homocysteine levels (14), whilst vitamin $\mathrm{B}_{12}$ deficiency is associated with pernicious anaemia in infants (15) and elderly populations and patients with intestinal disease $(16,17)$.

Recent findings from the EPIC Study (18) showed gender- and region-specific differences in the intakes of retinol, $\beta$-carotene, vitamins $\mathrm{D}$ and $\mathrm{E}$ in 10 European countries together with significant heterogeneity in dietary patterns and incidence of cancer. Differences in intakes and dietary sources of vitamins such as the B vitamins (from meat) and vitamin $\mathrm{C}$ (from fruit and vegetables) have also been reported from this extensive investigation. However, the lack of a standardised nutrient database has been identified as a major obstacle to determining reliable nutrient intakes across Europe (19). The dietary importance of vitamins across the populations demands a greater knowledge of vitamin composition in foods, especially in cooked and ready-to-eat foods, in order that their intakes can be accurately calculated.

Vitamins are known to be affected by different processing methods, including frying, boiling, baking, grilling, and microwave cooking. Riboflavin $\left(\mathrm{B}_{2}\right)$, pyridoxine $\left(\mathrm{B}_{6}\right)$ and biotin are usually stable to domestic cooking whilst thiamin $\left(\mathrm{B}_{1}\right)$ and vitamins $\mathrm{A}, \mathrm{C}$ and $\mathrm{E}$, are relatively labile. For such labile compounds, the processing conditions, including duration and nature of storage, must be taken into account when determining their contents (20). This means that it is crucial that analytical data are obtained from foods as eaten. Because of the wide variation in techniques of production and of ingredient proportions in ethnic foods, there is an additional need to fully describe and analyse available ethnic foods by accurate methods in order to fill the gaps in national food composition data.

\section{Present investigation}

\section{Sampling}

A total of 30 commonly-consumed ethnic foods, five foods each from Belgium, France, Israel, Italy, The Netherlands and the UK, were prioritised according to set criteria including market share, popularity through sale outlets and consumption data (22). The food products analysed represented different cuisines: North African and Maghreb (from France); Israel/MediterraneanEthiopian (Israel); Latin American and Asian (Spain); Surinamese (The Netherlands) and Congolese (Belgium). Foods were divided into two categories: 1) modified ethnic foods, consumed by mainstream populations, which were collected from supermarkets, restaurants and takeaways, and 2) authentic ethnic foods (mainly consumed by ethnic minority groups) which were either home-made or obtained from ethnic food stores. Primary samples of modified (the majority of which numbered between 3 and 12 apart from molokhia sauce, yellow split peas and pamtayer leaves which were each available as single primary sample) and authentic (six samples of each) foods were combined to make a composite sample. All the samples were prepared in edible form and stored at $20^{\circ} \mathrm{C}$ prior to analysis.

\section{Analysis}

The vitamins were analysed at accredited laboratories using the harmonised approaches for sampling, food description, data scrutiny and documentation developed within the EuroFIR project (21). Samples were analysed at eight accredited laboratories; CAR LAREBRON (France), Standard Institute of Israel (Israel), CEINAL (Spain), Technical University of Denmark (DTU, Denmark); Neotron (Italy), UGhent and Chemphar (Belgium) and Eurofins (UK). International standard methods for $\beta$-carotene, all trans-retinol, vitamins $\mathrm{D}_{3}$ and $\mathrm{E}$ $(\alpha$-tocopherol), and selected water-soluble vitamins (vitamins $\mathrm{C}, \mathrm{B}_{6}, \mathrm{~B}_{12}$, folate, and thiamine, riboflavin, niacin, biotin and pantothenic acid) were used (Table 1).

\section{Results and discussion}

The foods examined in this study were selected to generate new and reliable data for inclusion in national databases. Such data are required for a wide variety of purposes including national food consumption and nutrition surveys. New data on 12 vitamins and $\beta$-carotene in 30 ethnic foods consumed in six countries are presented, as per $100 \mathrm{~g}$ edible portion, in Table $2 \mathrm{a}$ and $\mathrm{b}$.

\section{Fat soluble vitamins}

Retinol, a type of vitamin A (23), which is beneficial to humans because of its crucial role in vision and bone growth (24), was present in very low levels or below the detection limit in the vast majority of foods except rasmalai (UK) which contained $62 \mu \mathrm{g} / 100 \mathrm{~g}$. Whilst some foods contained appreciable amounts of $\beta$-carotene, harrisa sauce $(4000 \mu \mathrm{g} / 100 \mathrm{~g})$ and tayer leaves $(7919 \mu \mathrm{g} /$ $100 \mathrm{~g}$ ) were found to be excellent sources of vitamin A, representing $83 \%$ and $165 \%$ of the recommended dietary intake, respectively (based on 700 and $900 \mu \mathrm{g} /$ day recommended for ages between 14-50 year) (24). Ethnic foods such as palak paneer $(4066 \mu \mathrm{g} / 100 \mathrm{~g})$, gajjeralla $(2324 \mu \mathrm{g} /$ $100 \mathrm{~g})$ and saag $(1514 \mu \mathrm{g} / 100 \mathrm{~g})$ which are consumed in the UK were also rich in $\beta$-carotene (25). Vitamin D was not present in any of the foods analysed whilst vitamin $\mathrm{E}$ varied between $0.07 \mu \mathrm{g} / 100 \mathrm{~g}$ (frik dry, France) and $12.4 \mu \mathrm{g} /$ 100g (meloukhia sauce, France). 
Table 1. Analytical methods used for vitamin analyses in ethnic foods

\begin{tabular}{|c|c|}
\hline Vitamin & Methods \\
\hline Vitamin A (all-trans-retinol) & HPLC-UV (BS EN I2823-I:2000), HPLC-DAD, (IDF standard I42), HPLC (NF EN I2823-I) \\
\hline â-carotene & HPLC-UV; HPLC-DAD (AOAC 45.I.03, 1995), HPLC (NF EN I2823-2) \\
\hline Vitamin $B_{12}$ & Microbiological (AOAC $960.46 \mathrm{I}$ and AOAC 952-20), ELISA (RIDASCREENFAST vitamin $B_{12}$ test Art. No:R2I02) \\
\hline Total Folate & Microbiological (AOAC 944.12/45.2.03, 1990)), ICP_MS \\
\hline Vitamin C & $\begin{array}{l}\text { HPLC (J. Agric. Food Chem. I } 984 \text { 32, 352-5), HPLC-FLU, (26, 27), HPLC-UV; HPLC (NF EN I4I30), titrimetric } \\
\text { (AOAC 967.2I), HPLC-DAD (PNTQI00I) }\end{array}$ \\
\hline Vitamin E (á-tocopherol) & $\begin{array}{l}\text { HPLC (BS EN ISO 687:200I BS 5766:200I, NF V I8-I44; NF EN I2822), HPLC-FLU (AOCS Ce 8-89, revised I990; } \\
\text { PNTQI0I2) }\end{array}$ \\
\hline Vitamin $D_{3}$ & HPLC-UV (BS EN I282I:2000, NEN-EN I282I, 2000), HPLC (NF EN I282I), ISO/DIS I4892, I998) \\
\hline Vitamin $B_{3}$ (Niacin) & HPLC-UV (28), based on: J AOAC 76(5); microbiological method \\
\hline Pantothenic acid & Microbiological assay (AOAC 945.74, 1990) \\
\hline Vitamin $B_{6}$ & $\begin{array}{l}\text { HPLC - FLU (Food Chem 1993; 48:32I-324, Food Chem 1995; 52: 8I-86, (29); Arr du I2/0I/99, JORF du 04/02/99), } \\
\text { HPLC (XP ENV I4I64), based on: J AOAC 85(4); microbiological method }\end{array}$ \\
\hline Biotin & Turbidimetric (analogue to FDA method, LST AB 266.I), microbiological (AOAC 945-74) \\
\hline Thiamin (Vitamin $\left.B_{1}\right)$ & $\begin{array}{l}\text { HPLC - FLU (BS EN I4I22:2003; (30); PNTAI00I; AOAC 960-46), HPLC (NF EN I4I22), based on: } \\
\text { J AOAC 76(5) }\end{array}$ \\
\hline Riboflavin (Vitamin $B_{2}$ ) & $\begin{array}{l}\text { HPLC - FLU (BS EN 14I52:2003; (31); AOAC 960-46), HPLC (NF EN 14I52), Based on: } \\
\text { J AOAC 76(5) }\end{array}$ \\
\hline
\end{tabular}

Source: Khokhar et al., $2009^{22}$.

\section{Water soluble vitamins}

A vast majority of the foods analysed in this study contained water-soluble vitamins and, as anticipated, varied according to their composition and processing conditions.

Amongst the foods studied, thiamin was present in highest amounts in authentic falafel consumed in Israel $(0.30 \mathrm{mg} / 100 \mathrm{~g})$ whilst a commercial falafel product from Italy contained much lower levels $(0.17 \mathrm{mg} / 100 \mathrm{~g})$. Frik dry $(0.24 \mathrm{mg} / 100 \mathrm{~g}$, France) and sarmale $(0.20 \mathrm{mg} / 100 \mathrm{~g}$, Italy) contained appreciable amounts of this vitamin but most other foods contained below $0.10 \mathrm{mg} / 100 \mathrm{~g}$. Riboflavin was present in highest amounts in mbinzo worms $(0.79 \mathrm{mg} / 100 \mathrm{~g}$, Belgium). Thiamin, niacin and riboflavin and their co-enzymes play a key role in metabolism of carbohydrates, protein and fat. It is suggested that an intake of $0.6 \mathrm{mg} / 1000 \mathrm{kcal}$ for both thiamin and riboflavin meets the needs of most healthy adults (19). The range of niacin (not found in all samples) varied between $0.05 \mathrm{mg} / 100 \mathrm{~g}$ (harrisa sauce and buttermilk, France) and $17.5 \mathrm{mg} / 100 \mathrm{~g}$ (commercial soy patty, Israel). Most food contained niacin except for rasmalai from UK. The current RDA for niacin is $16 \mathrm{mg} /$ day and $14 \mathrm{mg}$ /day for adult men and women, respectively $(5,14)$. 'Niacin' comprises two compounds, nicotinic acid and nicotinamide and may function in oxidative metabolism and electron transport system, and its deficiency may be associated with significant irritation and diarrhoea (6).
Of the foods in this study, only kebab samples from Italy and UK contained significant amounts of vitamin $\mathrm{B}_{12}(2 \mu \mathrm{g} / 100 \mathrm{~g}$, compared with a recommended daily intake of $1-2 \mu \mathrm{g} /$ day) (19). Foods analysed for folate contained only small amounts of this vitamin ranging between $0-68 \mu \mathrm{g} / 100 \mathrm{~g}$ in injera and frik, dry, respectively. Majority of foods analysed did not contain vitamin C, which was mainly due to heat losses because all of these foods were cooked or processed. Pantothenic acid analysis was conducted only on the five foods from France, and varied between $0.27 \mathrm{mg} / 100 \mathrm{~g}$ (meloukhia sauce) and $0.82 \mathrm{mg} / 100 \mathrm{~g}$ (frik dry), whilst biotin was found in most foods between $1.0 \mu \mathrm{g} / 100 \mathrm{~g}$ and $23 \mu \mathrm{g} / 100 \mathrm{~g}$.

The incompleteness of published food composition data in these ethnic foods, precluded comparison of the data determined with other studies. However, the present data were determined at accredited laboratories and certified references materials (CRM) were used to ensure the validity and reliability of data. These data are fully documented and are now included in national databases in the relevant countries.

\section{Conclusions}

The foods analysed in this study represent a wide variety of food products and varied in type of ingredients to include meat-based dishes, cereal and vegetable products. This diversity resulted in significant variations in the measured vitamin contents. It is concluded that tayer 
Table 2a. Vitamin composition of ethnic foods commonly consumed in Europe

\begin{tabular}{|c|c|c|c|c|c|c|c|c|c|c|c|c|c|c|}
\hline \multicolumn{15}{|c|}{ Vitamin composition of food per 100g edible portion } \\
\hline No & Food & Retinol & $\beta$-carotene & Thiamin & Riboflavin & Vitamin $\mathrm{B}_{6}$ & Vitamin $B_{12}$ & Folate & Niacin & Biotin & Pantothenic acid & Vitamin C & Vitamin E & Vitamin D \\
\hline & & $\mu \mathrm{g}$ & $\mu \mathrm{g}$ & $\mathrm{mg}$ & $\mathrm{mg}$ & $\mathrm{mg}$ & $\mu \mathrm{g}$ & $\mu \mathrm{g}$ & $\mathrm{mg}$ & $\mu \mathrm{g}$ & $\mathrm{mg}$ & $\mathrm{mg}$ & $\mathrm{mg}$ & $\mu \mathrm{g}$ \\
\hline \multicolumn{15}{|c|}{ France } \\
\hline 1 & Brik pastry sheet, baked & .. & 50 & 0.09 & 0.05 & 0.08 & $<\mathrm{DL}$ & 12.4 & 1.7 & 5.5 & 0.42 & .. & $<\mathrm{DL}$ & $<\mathrm{DL}$ \\
\hline 2 & Harrisa sauce & .. & 4000 & $<\mathrm{DL}$ & 0.21 & 0.26 & $<\mathrm{DL}$ & 28.0 & 0.05 & 23.0 & 0.52 & .. & 6.1 & $<\mathrm{DL}$ \\
\hline 3 & $\begin{array}{l}\text { Buttermilk, cultured, low fat, } \\
\text { plain }\end{array}$ & .. & 50 & 0.05 & 0.20 & 0.05 & 0.24 & 7.8 & 0.05 & 2.8 & 0.38 & .. & 0.1 & $<\mathrm{DL}$ \\
\hline 4 & Frik, dry $(5|5| I)$ & .. & 50 & 0.24 & 0.09 & 0.14 & $<\mathrm{DL}$ & 68.2 & 0.05 & 6.8 & 0.82 & .. & 0.1 & $<\mathrm{DL}$ \\
\hline 5 & Meloukhia sauce &.. & 83 & $<\mathrm{DL}$ & 0.09 & $<\mathrm{DL}$ & $<\mathrm{DL}$ & 28.4 & 0.05 & 12.3 & 0.27 & .. & 12.4 & $<\mathrm{DL}$ \\
\hline \multicolumn{15}{|c|}{ Israel } \\
\hline 6 & Falafel & $<\mathrm{DL}$ & 82 & 0.30 & $<\mathrm{DL}$ & 0.20 & $<\mathrm{DL}$ & 8.8 & 15.9 & 7.1 & .. & 1.2 & 3.1 & $<\mathrm{DL}$ \\
\hline 7 & Dark bread & 100 & $<\mathrm{DL}$ & 0.18 & $<\mathrm{DL}$ & 0.10 & $<\mathrm{DL}$ & $<\mathrm{DL}$ & 3.7 & 1.0 & .. & 2.2 & 0.6 & $<\mathrm{DL}$ \\
\hline 8 & Commercial soy patty & $<\mathrm{DL}$ & 168 & 0.06 & 0.60 & 0.50 & $<\mathrm{DL}$ & $<\mathrm{DL}$ & 17.5 & 1.4 & .. & 7.7 & 5.1 & $<\mathrm{DL}$ \\
\hline 9 & Injera & 300 & $<\mathrm{DL}$ & 0.17 & $<\mathrm{DL}$ &.. & $<\mathrm{DL}$ & $<\mathrm{DL}$ & 8.7 & 3.4 & .. & 1.5 & 2.0 & $<\mathrm{DL}$ \\
\hline 10 & Commercial hummus & $<\mathrm{DL}$ & 17 & $<\mathrm{DL}$ & 0.05 & 0.20 & $<\mathrm{DL}$ & $<\mathrm{DL}$ & $<\mathrm{DL}$ & 4.5 & .. & 12 & 3.3 & $<\mathrm{DL}$ \\
\hline \multicolumn{15}{|l|}{ Italy } \\
\hline 21 & Cantonese rice & $<\mathrm{DL}$ & 12 & 0.17 & 0.09 & 0.05 & .. & .. & 1.4 & $<\mathrm{DL}$ & .. & $<\mathrm{DL}$ & 1.3 & .. \\
\hline 22 & Nachos & $<\mathrm{DL}$ & $<\mathrm{DL}$ & 0.16 & 0.10 & 0.13 & .. &.. & 1.7 & $<\mathrm{DL}$ & .. &.. & 3.94 & .. \\
\hline 23 & Falafel (Italy) & $<\mathrm{DL}$ & $<\mathrm{DL}$ & 0.11 & 0.08 & 0.06 & .. & .. & 0.7 & $<\mathrm{DL}$ & .. & .. & 4.98 &.. \\
\hline 24 & Kebab & 4 & $<\mathrm{DL}$ & 0.13 & 0.38 & 0.14 & 2 & .. & 1.0 & $<\mathrm{DL}$ & .. & .. & 0.52 & .. \\
\hline 25 & Sarmale & $<\mathrm{DL}$ & $<\mathrm{DL}$ & 0.20 & 0.08 & 0.05 & $<\mathrm{DL}$ & .. & 2.0 & $<\mathrm{DL}$ & .. & 2.59 & 0.13 & .. \\
\hline
\end{tabular}

.. - not determined; <DL - below detectable level. 
Table $2 b$. Vitamin composition of ethnic foods commonly consumed in Europe

\begin{tabular}{|c|c|c|c|c|c|c|c|c|c|c|c|c|c|c|}
\hline \multicolumn{15}{|c|}{ Vitamin composition of food per 100g edible portion } \\
\hline No & Food & Retinol & $\beta$-carotene & Thiamin & Riboflavin & Vitamin $B_{6}$ & Vitamin $B_{12}$ & Folate & Niacin & Biotin & Pantothenic acid & Vitamin C & Vitamin E & Vitamin D \\
\hline & & $\mu \mathrm{g}$ & $\mu g$ & $\mathrm{mg}$ & $\mathrm{mg}$ & $\mathrm{mg}$ & $\mu g$ & $\mu g$ & $\mathrm{mg}$ & $\mu g$ & $\mathrm{mg}$ & $\mathrm{mg}$ & $\mathrm{mg}$ & $\mu \mathrm{g}$ \\
\hline \multicolumn{15}{|c|}{ The Netherlands } \\
\hline 26 & Roti (chapatti) & $<\mathrm{DL}$ & $<\mathrm{DL}$ & 0.06 & 0.04 & 0.09 & .. & 13 & 0.7 & .. & .. & .. & 6.34 & .. \\
\hline 27 & Salted meat & 100 &.. & 0.01 & 0.12 &.. & .. &.. &.. & .. & .. & .. &.. & .. \\
\hline 28 & Tayer leaves &.. & 7919 & 0.04 & 0.53 & .. & .. & .. & .. & .. & .. &.. & 1.32 &.. \\
\hline 29 & Pomtayer & $<\mathrm{DL}$ & 513 & 0.03 & 0.07 &.. & .. & .. & .. &.. & .. &.. &.. &.. \\
\hline 30 & Yellow split peas &.. & $<\mathrm{DL}$ & 0.26 & 0.04 &.. & .. & .. &.. &.. & .. &.. & .. & .. \\
\hline \multicolumn{15}{|c|}{ Belgium } \\
\hline 31 & Makayabo & $<\mathrm{DL}$ & .. & 0.03 & 0.31 &.. & .. & .. & .. & .. & .. &.. & .. & .. \\
\hline 32 & Saka-saka & $<\mathrm{DL}$ & .. & 0.07 & 0.31 & .. & .. & .. & .. &.. & .. & 15 &.. & .. \\
\hline 33 & Chikwangue &.. &.. & 0.06 & 0.04 & .. & .. & .. &.. & .. & .. &.. & .. & .. \\
\hline 34 & Mbinzo worms &.. & & 0.02 & 0.79 & & & & & & &.. & & \\
\hline 35 & Biteku-teku & $<\mathrm{DL}$ & .. & $<\mathrm{DL}$ & 0.12 & .. & .. & .. & .. & .. & .. & $<\mathrm{DL}$ & .. & .. \\
\hline \multicolumn{15}{|c|}{ United Kingdom } \\
\hline 36 & Chicken bhuna & $<\mathrm{DL}$ & 522 & 0.02 &.. & 0.15 & $<\mathrm{DL}$ & 7 & 2.6 & 4.6 & .. & .. & 1.55 & $<\mathrm{DL}$ \\
\hline 37 & Lamb kebab & $<\mathrm{DL}$ & 166 &.. & 0.06 & 0.17 & 2 & 12 & 3.1 & 6.7 & .. &.. & 0.67 & $<\mathrm{DL}$ \\
\hline 38 & Aloo Bombay & $<\mathrm{DL}$ & 646 & 0.01 & 0.02 & $<\mathrm{DL}$ & .. & 7 & 0.8 &.. & .. & $<\mathrm{DL}$ & 1.83 &.. \\
\hline 39 & Rasmalai & 62 &.. &.. & 0.15 &.. & $<\mathrm{DL}$ &.. & $<\mathrm{DL}$ & 3.8 & .. &.. & 0.16 &.. \\
\hline 40 & Chicken rogan josh & $<\mathrm{DL}$ & 884 & 0.06 &.. & 0.14 & $<\mathrm{DL}$ & 14 & 2.3 & 4.0 & .. & 35 & 1.75 & $<\mathrm{DL}$ \\
\hline
\end{tabular}

.. - not determined; $<\mathrm{DL}-$ below detectable level. 
leaves (from Belgium) and harrisa sauce (from France) are excellent sources of $\beta$-carotene (containing 7919 and $4000 \mu \mathrm{g} / 100 \mathrm{~g}$, respectively) and may have value for optimising intakes of vitamin A due to the lack of retinol in other ethnic foods analysed in this study.

The majority of the foods contained most of the watersoluble vitamins but lacked fat-soluble vitamins. However, only five foods were examined from each country and clearly not all the data required to make firm conclusions about the nutritional adequacy of ethnic diets or a diet containing ethnic food are included. Until more foods are analysed, it is difficult to reach a conclusion about the need, if any, for optimising vitamin intakes through, for example, dietary fortification.

Foods presented are commonly consumed by mainstream populations and ethnic minority groups suggesting that these foods would be important for their contributions towards daily intakes of some of these vitamins. Ethnic minority groups consuming ethnic foods are amongst those possessing the least purchasing power and so are unlikely to vary their diets significantly and may also be at higher risk of adverse diet-related health conditions.

\section{Acknowledgements}

This work was completed on behalf of EuroFIR Network of Excellence and funded under the European Union's FP6 'Food Quality and Safety programme' (Contract No. FP6-513944). Authors would like to thank all the analytical laboratories.

\section{Conflict of interest and funding}

EU funding as written in the acknowledgements, no other funding from industry or anybody.

\section{References}

1. Jacob RA, Sotoudeh G. Vitamin $\mathrm{C}$ function and status in chronic disease. Nutr Clin Care 2002; 5: 66-74.

2. Voutilainen S, Nurmi T, Mursu J, Rissanen TH. Carotenoids and cardiovascular health. Am J Clin Nutr 2006; 83: 1265-71.

3. Wallis DE, Penckofer S, Sizemore GW. The 'Sunshine deficit' and cardiovascular disease. Circulation 2008; 14: 1476-85.

4. Giovannucci E. Epidemiological evidence for vitamin D and colorectal cancer. J Bone Mineral Res 2007; 22(2 Suppl): S81-S5.

5. Giovannucci E. Vitamin D status and cancer incidence and mortality. Adv Exp Med Biol 2008; 624: 31-42.

6. WHO (2009). Global Prevalence of vitamin A deficiency in populations at risk 1995-2005. Geneva:World Health Organisation. Available from: http://www.who.int/vmnis/vitamina/prevalence/en/index.html

7. Lin J, Song F, Yao P, Yang X, Li N, Sun S, et al. Effect of vitamin A supplementation on immune function of wellnourished children suffering from vitamin A deficiency in China. Eur J Clin Nutr 2008; 62(12): 1412-8.

8. Merewood A, Mehta SD, Grossman X, Chen TC, Mathieu JS, Holick MF, et al. Widespread Vitamin D deficiency in urban
Massachusetts newborns and their mothers. Pediatrics 2010; 125(4): 640-7.

9. Ekbote VH, Khadilkar AV, Mughal MZ, Hanumante N, Sanwalka N, Khadilkar VV, et al. Sunlight exposure and development of rickets in Indian toddlers. Indian J Pediatr 2010; 77(1): 61-5.

10. Unuvar T, Buyukgebiz A. Nutritional rickets and vitamin D deficiency in infants, children and adolescents. Pediatr Endocrinol Rev 2010; 7(3): 283-91.

11. Modgil G, Williams B, Oakley G, Burren CP. High prevalence of Somali population in children presenting with vitamin D deficiency in the UK. Arch Dis Child 2010; 95(7). DOI: 10.1136/ adc.2010.187435|ISSN 0003-9888.

12. Mulligan GB, Licata A. Taking vitamin D with the largest meal improves absorption and results in higher serum levels of 25hydroxy vitamin D. J Bone Miner Res 2010; 25(4): 928-30.

13. Blencowe H, Cousens S, Modell B, Lawn J. Folic acid to reduce neonatal mortality from neural tube disorders. Int $\mathbf{J}$ Epidemiol 2010; 9(1 Suppl): 110-21.

14. Armitage JM, Bowman L, Clarke RJ, Wallendszus K, Bulbulia R, Rahimi K, et al. Effects of homocysteine-lowering with folic acid plus vitamin B-12 vs placebo on mortality and major morbidity in myocardial infarction survivors-a randomized trial. J American Med Assoc 2010; 303(24): 2486-94.

15. Banka S, Roberts R, Plews D, Newman WG. Early diagnosis and treatment of cobalamin deficiency of infancy owing to occult maternal pernicious anemia. J Pediatr Hematol Oncol 2010; 32(4): 319-22.

16. Andres E, Kaltenbach G, Noblet-Dick M, Noel E, Vinzio S, Perrin AE, et al. Hematological response to short-term oral cyanocobalamin therapy for the treatment of cobalamin deficiencies in elderly patients. J Nutr Health \& Aging 2006; 10(1): 3-6.

17. Hvas AM, Nexo E. Diagnosis and treatment of vitamin B12 deficiency. An update Haematologica. Hematology J 2006; 91(11): 1506-12.

18. Jenab M, Salvini S, van Gils CH, Brustad M, Shakya-Shrestha S, Buijsse B, et al. Dietary intakes of retinol, beta-carotene, vitamin D and vitamin $\mathrm{E}$ in the European Prospective Investigation into Cancer and Nutrition cohort. Eur J Clin Nutr 2009; 63: S150-S78.

19. Olsen A, Halkjaer J, van Gils CH, Buijsse B, Verhagen H, Jenab $\mathrm{M}$, et al. Dietary intake of the water-soluble vitamins B1, B2, B6, B12 and C in 10 countries in the European prospective investigation into cancer and nutrition. Eur J Clin Nutr 2009; 63: S122-49.

20. Dionísio AP, Gomes RT, Oetterer M. Ionizing radiation effects on food vitamins-a review. Brazilian Arch Biol Tech 2009; 52(5): 1267-78.

21. Finglas PM, van den Berg BH, de Froidmont-Giirtf I. Improvements in the determination of vitamins in foods: method inter-comparison studies and preparation of certified reference materials (CRMs). Food Chem 1996; 57(1): $91-4$.

22. Khokhar S, Gilbert PA, Moyle CWA, Carnovale E, Shahar DR, $\mathrm{Ngo}$ J, et al. Harmonised procedures for producing new data on the nutritional composition of ethnic foods. Food Chem 2009; 113(3): 816-24.

23. Food and Nutrition Board. Institute of Medicine. Dietary reference intakes for vitamin $\mathrm{A}$, vitamin $\mathrm{K}$, arsenic, boron, chromium, copper, iodine, iron, manganese, molybdenum, nickel, silicon, vanadium, and zinc. Washington, DC: National Academy Press, 2001.

24. Lukaski HC. Vitamin and mineral status: effects on physical performance. Nutr 2004; 20(7-8): 632-44. 
25. Khokhar S, Roe M, Swan G. Carotenoid and retinol composition of South Asian foods commonly consumed in the UK. J Food Composit Anal 2012; 25(2): 166 -72.

26. Zapata S, Dufour JP. Ascorbic, dehydroascorbic and isoascorbic acid simultaneous determinations by reverse phase ion interaction HPLC. J Food Sci 1992; 57(2): 506-11.

27. Dodson KY, Young ER. Soliman AGM. Determination of total vitamin-c in various food matrices by liquid-chromatography and fluorescence detection. Journal of AOAC International 1992; 75(5): 887-91.

28. Takatsuki K, Suzuki S, Sato M, Sakai K, Ushizawa I. Liquidchromatographic determination of free and added niacin and niacinamide in beef and pork. Journal of the Association of Official Analytical Chemists 1987; 70(4): 698-702.

29. Brubacher G, Muller-Mulot W, Southgate DAT. In "Methods for the determination of vitamins in food". Elsevier Applied Science Publishers Ltd, London. 1985.
30. Gubler CJ, Thiamin Machlin, 1.J. (Ed.). In: Machlin LJ, ed. Handbook of Vitamins, Second Edition. New York and Basel: Marcel Dekker. 1991: 233-282.

31. Cooperman JM, Lopez R. Riboflavin. In: Machlin LJ, ed. Handbook of Vitamins, Second Edition. New York and Basel: Marcel Dekker. 1991: 283-310.

\section{*Dr Santosh Khokhar}

School of Food Science \& Nutrition

University of Leeds

LS2 9JT, UK

Phone: +44-II 33432975

Fax: +44-II33432982

Email: s.khokhar@food.leeds.ac.uk 